\title{
PEMBELAJARAN KOOPERATIF BERBASIS LKS UNTUK MENINGKATKAN MOTIVASI DAN HASIL BELAJAR PADA MATA PELAJARAN TIK SISWA KELAS X SMAK SANTO PAULUS SINGARAJA
}

\author{
Oleh \\ Ni Putu Linda Ariastini \\ Jurusan Pendidikan Teknik Informatika, FTK, UNDIKSHA
}

\begin{abstract}
ABSTRAK
Penelitian ini bertujuan untuk (1) meningkatan motivasi belajar siswa pada mata pelajaran TIK melalui metode kooperatif berbasis LKS, (2) meningkatan hasil belajar siswa pada mata pelajaran TIK melalui metode kooperatif berbasis LKS, (3) mendeskripsikan respon siswa terhadap penerapan pembelajaan kooperatif berbasis LKS pada mata pelajaran TIK.

Penelitian ini adalah penelitian tindakan kelas yang dilaksanakan dalam dua siklus pembelajaran. Subjek penelitian ini adalah siswa kelas X SMAK Santo Paulus Singaraja tahun pelajaran 2009/2010 yang berjumlah 29 orang. Objek penelitian ini adalah motivasi belajar, hasil belajar dan respon siswa. Metode pengumpulan data yang dipergunakan adalah (1) metode observasi yang digunakan untuk memperoleh data motivasi belajar, (2) metode tes yang digunakan untuk memperoleh data hasil belajar, (3) kuisioner digunakan untuk memperoleh data respon siswa terhadap pembelajaran kooperatif. Semua data dalam penelitian ini dianalisis menggunakan statistik deskriptif kuantitatif.

Hasil penelitian menunjukkan (1) terjadi peningkatan rata-rata motivasi belajar siswa pada pelajaran teknologi informasi dan komunikasi sebesar 2,12 atau $15 \%$ yaitu pada siklus I rata-rata motivasi belajar siswa sebesar 11,60 dengan kualifikasi cukup tinggi sedangkan pada siklus II sebesar 13,72 dengan kualifikasi tinggi, (2) terjadi peningkatan rata-rata hasil belajar siswa sebesar 3,2\% yaitu pada siklus I sebesar 73,79 dengan ketuntasan klasikal sebesar 75,86\% meningkat menjadi 76,25 dengan ketuntasan klasikal sebesar $100 \%$ pada siklus II, (3) Respon siswa terhadap penerapan metode kooperatif berbasis LKS pada mata pelajaran TIK adalah positif dengan rata-rata sebesar 78,28.
\end{abstract}

Kata-kata kunci: pembelajaran kooperatif, motivasi belajar, hasil belajar

\begin{abstract}
This research purpose to (1) improving students motivation in study of TIK subject by using cooperative method based-LKS, increasing the result of study in TIK subject by the students using cooperative method with LKS-based, (3) describing students response toward application of cooperative study based-LKS in TIK subject.
\end{abstract}


This research was a classroom action research conducted by two cycles of study. The subjects of study were the students grade X SMAK Santo Paulus Singaraja in academic year 2009/2010. Further, the object of this research were motivation, result of study and students response. Then, the method which used to collect data were (1) observation that used to get study motivation data, (2) test was used to get study's result data, (3) questionnaire was used to get students response data in cooperative study. all data in this research analyzed by using statistic descriptive and quantitative.

The of the research showed that (1) there was improvements in students motivation of study in TIK subject (Technology of Information and Communication) approximately was 2,12 or $15 \%$, (2) improvement of the students result in this study approximately was $3,2 \%$ (3) finally, students response in applying cooperative study based-LKS of TIK was positive response, then approximately was 78,28 .

Key words: cooperative study, study motivation, result of study

\section{PENDAHULUAN}

Pemerintah sangat memperhatikan kualitas pendidikan, hal ini dapat dilihat dengan dicantumkannya pendidikan dalam Undang-Undang Dasar 1945. Untuk meningkatkan kualitas pendidikan, pemerintah membuat program pendidikan yang dapat meningkatkan kualitas pendidikan rakyat Indonesia. Salah satunya yaitu mengatasi permasalahan pada saat proses pembelajaran, seperti yang terjadi di kelas X SMAK Santo Paulus Singaraja.

Sebelum mengadakan penelitian, penulis telah mengadakan observasi awal ke SMAK Santo Paulus Singaraja dengan mewawancarai guru pengajar TIK dan Kepala Sekolah setempat. Berdasarkan hasil wawancara penulis, dari ketiga aspek penilaian yang ada pada mata pelajaran TIK, aspek pemecahan masalah yang kurang mencapai keberhasilan di kelas X. Untuk siswa tingkat SMA, aspek pemecahan masalah ini biasanya dilakukan dengan pemberian tugas-tugas. Namun, kebanyakan siswa kelas X di SMAK Santo Paulus tidak mencapai ketuntasan karena perolehan nilai pada aspek pemecahan masalah masih sangat standar dan belum mencapai hasil yang diharapkan. Selain itu penulis mendapatkan temuan sebagai berikut: 1) Tingkat kemampuan siswa di kelas X SMAK Santo Paulus Singaraja tidak merata, 2) Teknik dan metode pembelajaran yang dilakukan selama ini didominasi oleh guru sehingga 
siswa hanya menerima informasi secara pasif, 3) Sistem pembelajaran yang dilakukan cenderung tidak membuat siswa paham tetapi menghafal materi yang diberikan.

Sesuai dengan permasalahan yang terjadi, maka perlu adanya upaya dalam memperbaiki metode pembelajaran yang telah berlangsung selama ini. Salah satunya dapat dilakukan dengan penerapan metode kooperatif berbasis LKS.

Metode ini dipandang cocok untuk mengatasi permasalahan di atas. Mengingat pembelajaran kooperatif merupakan pembelajaran yang secara sadar dan sengaja menciptakan interaksi yang saling mengasihi antar sesama siswa (Nurhadi, 2004; dalam Rustini, 2009). Pembelajaran kooperatif bersifat membelajarkan kepada siswa keterampilan kerjasama dan kolaborasi. Untuk lebih mendukung penerapan metode kooperatif ini, maka digunakanlah LKS untuk membantu siswa dalam kegiatan pembelajaran.

Berdasarkan uraian latar belakang serta identifikasi masalah di atas, dalam penelitian akan diterapkan pembelajaran kooperatif berbasis LKS dalam upaya peningkatan motivasi belajar dan hasil belajar siswa kelas X SMAK Santo Paulus pada mata pelajaran TIK.

Pembelajaran kooperatif adalah pembelajaran yang jangkauannya melampaui belajar isi akademik dan keterampilan semata, namun juga melatih siswa untuk mencapai tujuan-tujuan hubungan sosial dan manusia serta menuntut kerjasama siswa dalam kelompok dan saling ketergantungan dalam struktur tugas, tujuan dan hadiah. (Ibrahim, 2000).

Motivasi merupakan dorongan mental yang menggerakkan dan mengarahkan perilaku manusia, termasuk perilaku belajar (Dimyati dan Mudjiono, 2006). Suryabrata (dalam Syahruddin, 2006) menyatakan bahwa hasil belajar merupakan prestasi yang dapat dilihat dari nilai rapor yang merupakan perwujudan atau rumusan terakhir dari yang dilakukan guru dalam memberikan penilaian kepada siswa.

Teknologi informasi adalah suatu teknologi yang digunakan untuk mengolah data, termasuk memproses, mendapatkan, menyusun, menyimpan, memanipulasi data dalam berbagai cara untuk menghasilkan informasi yang 
berkualitas, yaitu informasi yang relevan, akurat dan tepat waktu, yang digunakan untuk keperluan pribadi, bisnis, dan pemerintahan dan merupakan informasi yang strategis untuk mengambil keputusan.

Seorang guru harus pintar-pintar memilih metode pembelajaran yang dilakukan agar pembelajaran lebih bermakna dan interaktif demi tercapainya tujuan pembelajaran yang diharapkan. Salah satu mata pelajaran yang mengalami permasalahan didalam pembelajarannya adalah mata pelajaran TIK khususnya terhadap aspek pemecahan masalah. Maka salah satu alternatif pembelajaran yang digunakan adalah dengan menerapkan pembelajaran kooperatif berbasis LKS. Melalui penerapan pembelajaran ini siswa dapat termotivasi dalam belajar dan mengerjakan tugas-tugas yang diberikan oleh guru serta mencoba mencari pemecahan masalah sehingga diperoleh kesimpulan yang jelas. Berdasarkan kajian teori dan kerangka berpikir di atas, maka dapat dirumuskan hipotesis tindakan yaitu: 1) penerapan Metode Kooperatif berbasis LKS dapat meningkatan motivasi belajar siswa pada mata pelajaran TIK, 2) penerapan Metode Kooperatif berbasis LKS dapat meningkatan hasil belajar siswa pada mata pelajaran TIK, 3) Respon siswa terhadap penerapan pembelajaran kooperatif berbasis LKS pada mata pelajaran TIK adalah positif.

\section{METODE PENELITIAN}

Penelitian ini dilaksanakan pada semester ganjil tahun ajaran 2009/2010 di Sekolah Menengah Atas Katolik Singaraja Jl. Kartini No.1 Singaraja dengan subjek penelitian yang akan diteliti dalam penelitian ini adalah siswa kelas X SMAK Santo Paulus Singaraja pada mata pelajaran TIK. Objek penelitian ini adalah: 1) Motivasi Belajar Siswa, 2) Hasil Belajar Siswa, dan 3) Respon siswa. Penelitian ini dilakukan dengan teknik penelitian tindakan kelas yang bertujuan untuk memperbaiki kualitas pembelajaran pada mata pelajaran TIK khususnya pada aspek pemecahan masalah.

Adapun tahapan penelitian tindakan kelas yaitu sebagai berikut: (1) Perencanaan tindakan, (2) pelaksanaan tindakan, (3) observasi atau monitoring tindakan dan hasil-hasilnya, dan (4) evaluasi dan refleksi tindakan dan hasil-hasilnya (Wardhani danWihardit, 2008). Sedangkan untuk intrumen dan pengumpulan data 
dapat dikumpulkan dengan observasi menggunakan lembar observasi belajar untuk motivasi belajar, data hasil belajar dikumpulkan dengan tes hasil belajar model essay, sedangkan untuk data respon siswa dikumpulkan dengan menggunakan kuisioner angket tertutup.

Data penilaian motivasi belajar siswa dianalisis secara deskriptif kuantitatif. Kualifikasi motivasi belajar siswa dikatakan berhasil apabila berada pada kualifikasi cukup tinggi, tinggi dan sangat tinggi. Jenjang kualifikasi dikategorikan berdasarkan rata-rata skor $(\bar{x})$, Mean Ideal (MI) dan Standar Deviasi Ideal (SDI.

Nilai $(\bar{x})$ dapat dihitung dengan menggunakan rumus :

$$
(\bar{x})=\frac{\sum X}{N}
$$

Dengan : $(\bar{x})=$ skor rata-rata motivasi belajar

$$
\begin{aligned}
\sum X & =\text { jumlah seluruh skor } \\
\mathrm{N} & =\text { jumlah siswa } \\
\mathrm{MI} & =1 / 2(\text { skor tertinggi ideal }+ \text { skor terendah ideal }) \\
\text { SDI } & =1 / 6 \text { (skor tertinggi ideal }- \text { skor terendah ideal })
\end{aligned}
$$

Hasil belajar dianalisis secara deskriptif kuantitatif berdasarkan nilai ratarata yang dicapai oleh siswa selama proses pembelajaran berlangsung baik itu berupa diskusi kelompok, pengerjaan LKS, tugas maupun laporan hasil diskusi kelompok.

Tabel 1. Rentang Nilai Hasil Belajar Siswa

\begin{tabular}{|c|l|l|}
\hline No & \multicolumn{1}{|c|}{ Skor } & \multicolumn{1}{c|}{ Kualifikasi } \\
\hline 1 & $90-100$ & Sangat tuntas \\
\hline 2 & $70-84$ & Tuntas \\
\hline 3 & $65-69$ & Cukup tuntas \\
\hline 4 & $<65$ & Tidak Tuntas \\
\hline
\end{tabular}

Peningkatan hasil belajar siswa pada mata pelajaran dilakukan melalui siklus pertama dan siklus kedua yang menggunakan rumus sebagai berikut :

a. Menentukan rata-rata 
(2.2)

$$
(\bar{x})=\underline{\text { Jumlah nilai siswa }}
$$

Jumlah siswa

b. Menentukan ketuntasan individual

(2.3)

$$
\mathrm{KI}=\underline{\text { Nilai yang dicapai siswa }} \times 100 \%
$$

Nilai maksimal

c. Menghitung ketuntasan klasikal

$$
\mathrm{KK}=\underline{\text { Jumlah siswa yang tuntas }} \mathrm{x} 100 \%
$$

Jumlah siswa seluruhnya

Dengan ketentuan, sesuai dengan kurikulum sekolah apabila ketuntasan klasikal mencapai $\geq 85 \%$, maka kelas yang bersangkutan dianggap tuntas.

Data mengenai respon siswa terhadap metode pembelajaran yang diterapkan dapat dianalisis secara deskriptif kuantitatif yaitu dengan menganalisis respon siswa menggunakan skala likert dengan lima alternatif jawaban.

\section{HASIL DAN PEMBAHASAN}

\subsection{Motivasi Belajar Siklus I}

Analisis motivasi belajar pada siklus I menunjukkan bahwa secara klasikal nilai rata-rata yang diperoleh sebesar 11.60 dan berada pada kualifikasi Cukup Tinggi. Dengan siswa yang tergolong memiliki motivasi belajar cukup tinggi sebanyak $48,28 \%$ dan yang memiliki motivasi kualifikasi tinggi sebanyak 51,74\%.

\subsection{Hasil Belajar Siklus II}

Nilai hasil belajar siswa pada siklus I adalah sebagai berikut : siswa yang tuntas sebanyak 13 orang atau sebesar $44,83 \%$, siswa yang berada pada kualifikasi cukup tuntas sebanyak 9 orang yaitu sebesar 31,03\%, siswa yang tidak tuntas sebanyak 7 orang atau sebesar $24,14 \%$, sedangkan siswa yang berada pada kualifikasi sangat tuntas sebesar $0 \%$ atau tidak ada siswa yang berada pada kualifikasi sangat tuntas 


\subsection{Motivasi Belajar Siklus II}

Analisis motivasi belajar pada siklus II menunjukkan bahwa secara klasikal nilai rata-rata yang diperoleh sebesar 13,72 dan berada pada kualifikasi Tinggi. Dengan siswa yang tergolong memiliki motivasi belajar sangat tinggi sebanyak 7 orang atau sebesar $24,14 \%$, siswa yang memiliki motivasi dengan kualifikasi tinggi sebanyak 16 orang atau sebesar $55,17 \%$ dan siswa yang memiliki motivasi belajar dengan kualifikasi cukup tinggi sebanyak 6 orang atau sebesar 20,69\%. Sedangkan analisis motivasi belajar dengan kualifikasi kurang dan sangat kurang sebesar 0\% yang berarti tidak ada siswa yang berada pada kualifikasi tersebut.

Rata-rata motivasi pada siklus II yang mencapai 13,72, bila dibandingkan dengan rata-rata motivasi belajar pada siklus I mengalami peningkatan sebesar 2,12 atau $15 \%$

\subsection{Hasil Belajar Siklus II}

Nilai hasil belajar siswa pada siklus II adalah sebagai berikut : siswa yang sangat tuntas sebanyak 4 orang atau sebesar 13,79\% siswa yang berada pada kualifikasi tuntas sebanyak 18 orang atau sebesar 62,07\%, kualifikasi cukup tuntas sebanyak 7 orang yaitu sebesar $24,14 \%$, dan siswa yang tidak tuntas sebesar $0,00 \%$ atau tidak ada siswa yang berada pada kualifikasi tidak tuntas.

Bila dibandingkan dengan nilai rata-rata kelas siswa yang diperoleh pada siklus I, nilai rata-rata pada siklus II mengalami peningkatan sebesar 2,46. Begitu juga terhadap ketuntasan klasikal pada siklus II yang mencapai 100\% jika dibandingkan dengan ketuntasan klasikal pada siklus I yang mencapai 75,86\% meningkat sebesar $24,14 \%$.

\subsection{Respon Siswa}

Data respon siswa terhadap metode kooperatif yang penulis terapkan di kelas X SMAK Santo Paulus Singaraja disebarkan dengan angket respon siswa sebanyak 20 pernyataan, baik itu pernyataan positif maupun pernyataan negatif. Setiap pernyataan mempunyai skor maksimum 5 dan skor minimum 1, sehingga diperoleh skor tertinggi 100 dan skor terendah 20. 
Analisis hasil respon siswa menunjukkan bahwa siswa yang memberikan respon sangat setuju sebesar 41,38\% dan respon setuju sebesar 58,62\%. Sedangkan untuk respon ragu-ragu, tidak setuju dan sangat tidak setuju sebesar 0\%. Dapat disimpulkan bahwa respon siswa terhadap penerapan metode kooperatif berbasis LKS secara klasikal berada pada kualifikasi setuju dengan rata-rata sebesar 78,28.

\section{PENUTUP}

Berdasarkan hasil penelitian dan pembahasan yang telah dipaparkan pada Bab IV, dapat disimpulkan bahwa: 1) penerapan metode kooperatif berbasis LKS dapat meningkatkan motivasi belajar pada mata pelajaran TIK dengan rata-rata motivasi belajar pada siklus I sebesar 11,60 dengan kualifikasi cukup tinggi dan pada siklus II sebesar 13,72 dengan kualifikasi tinggi sehingga terjadi peningkatan sebesar $15 \%$, 2) penerapan metode kooperatif berbasis LKS dapat meningkatkan hasil belajar pada mata pelajaran TIK dengan rata-rata hasil belajar siswa pada siklus I sebesar 73,79 dengan kualifikasi tuntas dan pada siklus II sebesar 76,25 dengan kualifikasi tuntas sehingga terjadi peningkatan sebesar 3,2\%, 3) respon siswa terhadap penerapan metode kooperatif berbasis LKS pada mata pelajaran TIK adalah positif dengan rata-rata sebesar 78,28.

\section{DAFTAR PUSTAKA}

Dimyati dan Moerdjiono. 2006. Belajar dan Pembelajaran. Jakarta: Rineka Cipta Hamalik, Oemar. 1994. Kurikulum dan Pembelajaran. Jakarta: Rineka Cipta

Ibrahim, Muslimin et.al. 2000. Pembelajaran Kooperatif. Surabaya: UNESAUniversity Press

Idakirei. 2008. Implikasi Teknologi Informasi dan Komunikasi Dalam Dunia Pendidikan. $\quad$ http://idakirei.wordpress.com/2008/06/04/implikasiteknologi-informasi-dan-komunikasi-dalam-dunia-pendidikan/. Diakses tanggal 23 Juli 2009 
Mulyasa. 2008. Kurikulum tingkat Satuan Pendidikan, Bandung: PT.Remaja Rosdakarya

Ramadhan, Tarmizi . 2008. Perbuatan Hasil Belajar. http://taufikbambang.info/?p=22. Diakses tanggal 24 Juli 2009

Retug, I Nyoman dan Suheimi Sya'ban. 2004. Pengembangan Model Pembelajaran Kolaboratif Untuk Meningkatkan Aktivitas Dan Hasil Belajar Mahasiswa Dalam Perkuliahan Kimia Fisika I. Laporan Penelitian (tidak diterbitkan) Undiksha Singaraja

Rustini, Ni Ketut. 2009. Penerapan Pembelajaran Kooperatif untuk Meningkatkan Prestasi dan Aktifitas Belajar pada Teknik Dasar Pengolahan Makanan Siswa Kelas $\mathrm{X}^{\mathrm{C}}$ SMK Negeri 3 Denpasar. Skripsi (tidak diterbitkan). Jurusan PKK Undiksha Singaraja

Setiawan, Wahyu Budi. 2008. Motivasi dan Pembelajaran. http://namce8081.wordpress.com/category/pendidikan/motivasi-belajar/. Diakses tanggal 24 Juli 2009

Slameto. 2003. Belajar dan Faktor-faktor yang Mempengaruhinya. Jakarta : Rineka Cipta

Suhadi, 2008. Teori Kebutuhan Maslow, Pendidikan di Indonesia, dan Unjuk Rasa Yang Santun. http://suhadinet.wordpress.com/tag/teori-kebutuhan-maslow/. Diakses tanggal 25 Juli 2009

Supriono. 2008. Penerapan Model Pembelajaran Kooperatif Peta Konsep untuk Meningkatkan Motivasi dan Hasil Belajar Siswa. http://jurnaljpi.wordpress.com/2008/04/12/supriono-2/. Diakses tanggal 23 Juli 2009

Syahruddin. 2006. Pembelajaran IPS berdasarkan kurikulum 2004 dengan memanfaatkan media peta dalam diskusi kelompok kecil untuk meningkatkan hasil belajar siswa kelas IV sekolah madrasah ibtidiyah negeri tegallinggah Singaraja. Laporan Penelitian (tidak diterbitkan). Jurusan pendidikan dasar FIP. Undiksha Singaraja

Syam, Jonni. 2008. Meningkatkan Hasil Belajar Pengetahuan Dasar Teknologi melalui Pembelajaran Kooperatif dengan Pendekatan STAD di SMK. http://bpgupg.go.id/index.php?view=article\&id=135\%3Ameningkatkanhasil-belajar-pengetahuan-dasar-teknologi-melalui-pembelajaran-kooperatifdengan-pendekatan-stad-di-smk\&option=com_content $\&$ Itemid=144.

Diakses tanggal 23 Juli 2009 
Triyana, Fajar. 2005. Implementasi Pendekatan Ketrampilan Proses Melalui Pemanfaatan Lks Untuk Meningkatkan Kompetensi Siswa Pada Pokok Bahasan Karakteristik Dan Jenis Transaksi Perusahaan Dagang Mata Pelajaran Akuntansi Kelas XI di SMA Muhammadiyah I Semarang. http://digilib.unnes.ac.id/gsdl/collect/skripsi/archives/HASH7cd9.dir/doc.pd f. diakses tanggal 7 Februari 2010

Wardhani dan Wihardit, Kuswaya. 2008. Penelitian Tindakan Kelas. Jakarta: Universitas Terbuka

Woolfolk, Anita. 2007. Educational Psychology. America : Pearson Education

Winkel, W.S. 2004. Psikologi Pengajaran. Yogyakarta: Media Abadi 